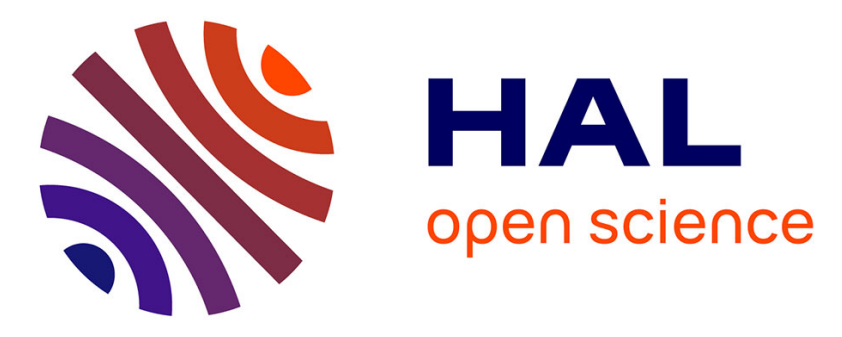

\title{
Ventilation performance and indoor air pollutants diagnosis in 21 French low energy homes
}

Gaëlle Guyot, Adeline Melois, Anne-Marie Bernard, Claire-Sophie Coeudevez, Suzanne Déoux, Sandra Berlin, Enora Parent, Alexis Huet, Sylvain Berthault, Romuald Jobert, et al.

\section{To cite this version:}

Gaëlle Guyot, Adeline Melois, Anne-Marie Bernard, Claire-Sophie Coeudevez, Suzanne Déoux, et al.. Ventilation performance and indoor air pollutants diagnosis in 21 French low energy homes. International journal of ventilation, 2017, pp.1 - 9. 10.1080/14733315.2017.1377393 . hal-01670490

\section{HAL Id: hal-01670490 https://hal.science/hal-01670490}

Submitted on 21 Dec 2017

HAL is a multi-disciplinary open access archive for the deposit and dissemination of scientific research documents, whether they are published or not. The documents may come from teaching and research institutions in France or abroad, or from public or private research centers.
L'archive ouverte pluridisciplinaire $\mathbf{H A L}$, est destinée au dépôt et à la diffusion de documents scientifiques de niveau recherche, publiés ou non, émanant des établissements d'enseignement et de recherche français ou étrangers, des laboratoires publics ou privés. 


\section{Ventilation performance and indoor air pollutants diagnosis in 21 French low energy homes}

Gaëlle Guyot ${ }^{1, *}$, Adeline Melois ${ }^{1}$, Anne-Marie Bernard ${ }^{2}$, Claire-Sophie Coeudevez ${ }^{3}$, Suzanne Déoux $^{3}$, Sandra Berlin ${ }^{3}$, Enora Parent ${ }^{1}$, Alexis Huet ${ }^{1}$, Sylvain Berthault ${ }^{1}$, Romuald Jobert ${ }^{1}$, Damien Labaume ${ }^{4}$

${ }^{1}$ CEREMA, 25 avenue François Mitterrand, CS 92803, 69674 BRON CEDEX, France

${ }^{2}$ Allie'Air, 4 Clos Ballet, Immeuble La Fenière, 01800 Meximieux, France

${ }^{3}$ MEDIECO Conseil \& Formation, 355 Allée Jacques Monod, 69800 Saint Priest, France

${ }^{4}$ ALDES aéraulique, 16 av Charles de Gaulle Bat 14, 31130 Balma, France

*Corresponding email: gaelle.guyot@cerema.fr

Keywords: Ventilation, indoor air quality, measurements, performance, low energy singlefamily homes

\section{SUMMARY}

Ventilation's historical goal has been to ensure sufficient air change rates in buildings from a hygienic point of view. Regarding its potential impact on energy consumption, ventilation is being reconsidered today. An important challenge for low energy buildings lies in the need to master airflows through the building envelope. Data collected from controls in 1287 recent dwellings shows us that $68 \%$ of the dwellings don't respect the French airing regulation. In this context, actors in the building's sector are reflecting on the risk of an unhealthy indoor air environment in this generation of high performance airtight dwellings.

"VIA-Qualité" project proposes to develop quality management (QM) approaches (ISO 9001) with the goal of increasing both on-site ventilation and indoor air quality in low energy houses.

The first step in this project consists in a campaign on 21 low-energy houses. First, we carried out an aeraulic measurement campaign on every dwelling including visual survey, airflow or pressure at the air-vents, ventilation duct airleakage, and acoustics measurements. Then, we selected 10 dwellings to carry out an indoor air quality winter campaign. This campaign included outdoor and indoor measurements of temperature, relative humidity, carbon dioxide, chemical pollutants (VOC, aldehydes). Inhabitant habits and building influence were studied through a complementary questionnaire survey.

With this campaign, we were able to identify ventilation dysfunctions and to compare them with the national statistics on dwelling stock. The second part of the measurement campaign allowed us also to identify links between aeraulic diagnoses and indoor pollutant measurements.

\section{INTRODUCTION}

In order to insure a good indoor air quality, including a proper humidity level in buildings, adequate air change rates are necessary. On the other side, building energy performance requires to rethink of ventilation and air change rates, because of their impact on thermal losses: 1) New ventilation systems technologies, such as Demand-Controlled Ventilation (DCV) systems, aim at restricting airflows to the minimum level for healthy buildings; 2) Envelope airtightness treatment becomes essential, especially for low energy dwellings (Erhorn et al., 2008). Indeed, envelope air leakage entails thermal losses, but also modifies theoretical voluntary airflows circuits in building. (Boulanger et al., 2012) confirmed 
that envelope airtightness drives to a better indoor air quality in low-energy buildings, thanks to a better mastering of the theoretical airflows circuits in buildings.

In France, the recent thermal regulation (RT2012) generalizes low energy dwellings and imposes envelope airtightness requirement for any new dwellings. For a single-family dwelling, the requirement is $\mathrm{Q}_{4 \mathrm{~Pa} \_ \text {Surf }}=0.6 \mathrm{~m}^{3} \cdot \mathrm{h}^{-1} \cdot \mathrm{m}^{-2}$, that is around $\mathrm{n}_{50}=2.3 \mathrm{~h}^{-1}$. This energy performance-regulation does not include any new requirement on ventilation rates. Dwellings airing is concerned by another 30 years old regulation (JO, 1982).

The "VIA-Qualité" project (2013-2016) focuses on low energy houses. As a first step, and in order to evaluate the ventilation system efficiency, we analysed available data from regulation compliance controls, related to several regulations, including energy performance (RT2005 \& 2012) and dwelling airing (1982-1983). Dysfunctions analysis of a 1287 dwellings sample allows us to establish an accurate picture of on-site ventilation systems quality (Jobert and Guyot, 2014): 47\% of the sample, do not comply with the airing regulation. The non-compliance rate is $68 \%$ for single-family dwellings, and $44 \%$ for multifamily dwellings. This analysis confirms others in Europe (Boersta, 2012; Caillou, 2012), which observe that in-site ventilation system mounting is often far from the hoped performance.

In this context, building's sector wonders about the risk for a generation of performing airtight dwellings to contribute to an unhealthy indoor air.

This project proposes developing quality management (QM) approaches (ISO 9001) with the goal of increasing both on-site ventilation and indoor air quality (IAQ). Such QM approaches, when applied to the individual homebuilder sector, appear to be promising. In France, the individual homebuilders sector accounts for the majority of new single-family dwellings. The benefits would be to: 1- Improve ventilation system performance, especially thanks to rigorous monitoring from conception to installation; 2- Limit indoor internal pollution sources, monitoring materials selection (Wargocki and Hartmann, 2012); 3- Increase final users awareness and understanding. Individual homebuilders, with respect to an annex of the French EP-regulation, are already using such QM approaches in envelope airtightness field. Feedback from these experiences shows that such approaches are both successful and affordable for either small or large individual homebuilder (Carrié R. et al, 2007) (Charrier S. et al, 2014).

As data on classical low-energy dwellings were missing, we have also conducted an original campaign on ventilation performance and IAQ in 21 low-energy dwellings representative for French buildings stock.

First, the paper presents quickly the methodologies used in this campaign of the "VIAQualité" project. Then, we present results and analysis of observed dysfunctions, leading to some proposals for ventilation installation improvement. Then, we present briefly IAQ results and analysis. Finally, we conclude and present briefly the follow-up of the campaign, and of the project.

\section{METHODS}

We have selected 21 low-energy houses, representative for classical French new lowenergy houses This sample includes 7 balanced ventilation with heat recovery systems and 14 humidity demand controlled ventilation (DCV) systems. On the whole sample, we conducted first ventilation performance measurements. Then, we selected 10 dwellings, with various kind and importance of non-compliance from a "ventilation point-of-view", to carry out an indoor air quality winter campaign. 8 of them have balanced ventilation with heat recovery, as there are only few feedbacks on this type of ventilation, and 2 have humidity demand controlled ventilation (DCV).

As a first step of this campaign, the ventilation performance evaluation consists in (Table 1): ventilation ducts leakage measurements, airflows (if balanced ventilation) or 
pressure differences (if DCV) at air outlets measurements, airflows at air supply (if balanced ventilation), noise level of the ventilation equipment measurements, and visual diagnostic of the installation regarding its compliance with French dwellings airing regulation (JO, 1982). We also perform envelope airleakage measurement, in the rare cases when such measurement reports are not available. The airing regulation requires general and continuous ventilation and describes the compulsory general layouts of ventilation installation. It also sets exhaust airflows in each humid room, depending on the total number of rooms in the dwelling. Total airflows drive to around $0.5 \mathrm{~h}^{-1}$ global air change rate in the dwelling. This regulation has been modified in 1983 in order to reduce these airflows in case of DCV system, for instance based on humidity, which are very often used in France. In this case, controls include also additional specific technical guidelines.

Tolerance margins for airflows and pressure measurements at out- and inlets are: \pm 3 $\mathrm{m}^{3} / \mathrm{h}$ for target airflows under $15 \mathrm{~m}^{3} / \mathrm{h} ; \pm 5 \mathrm{~m}^{3} / \mathrm{h}$ for target airflows over $15 \mathrm{~m}^{3} / \mathrm{h}$; measured pressure must be included in the $\left[\mathrm{P}_{\min }-5 \mathrm{~Pa} ; \mathrm{P}_{\max }+5 \mathrm{~Pa}\right]$ interval. Where $\mathrm{P}_{\min }$ and $\mathrm{P}_{\max }$ are respectively the minimum and the maximum working pressures of the outlet given by the manufacturer.

Total airflow in a dwelling is calculated summing measured airflows at outlets. In case of DCV system, we use the following formula to estimate the relative error $(\delta Q)$ to the minimum regulatory total airflow $\left(\mathrm{Q}_{\text {reg }}\right)$, starting from measured pressures at the $\mathrm{N}$ outlets (Pi).

$$
\delta Q=\frac{\Delta Q}{Q_{\text {reg }}}=\left(\frac{\sum_{i=1}^{N} P_{i}}{N * P_{\min }}\right)^{0.5}-1
$$

As a result, we define 3 categories of houses: 1) "Houses with regulatory airflow" have total measured airflow between $\mathrm{Q}_{\text {reg }}$ and $\left.1.3 * \mathrm{Q}_{\text {reg }} ; 2\right)$ "Houses with over-ventilation" have total measured airflow over $\left.1.3^{*} \mathrm{Q}_{\text {reg }} ; 3\right)$ "Houses with under-ventilation" have total measured airflow under $\mathrm{Q}_{\text {reg. }}$.

As a second step of this campaign, the IAQ evaluation consists in: indoor and outdoor pollutants measurements, hygrothermal and air stuffiness parameters measurements, and questionnaire surveys. The IAQ evaluation takes place during the winter 2014. The selected pollutants for the measurements (Table 2) are considered as priority for IAQ according to the French Indoor Air Quality Observatory (OQAI, 2013). During 7 days, 16 VOC, 8 aldehydes, $\mathrm{NO}_{2}, \mathrm{CO}$ (if there is a source of combustion in the dwelling), PM 2.5, $\mathrm{CO}_{2}$, temperature and relative humidity are measured in the living room and in a bedroom. Radon is measured during two months. VOC and $\mathrm{NO}_{2}$ are also measured outdoor.

The questionnaire surveys (OQAI, 2013) aims at describing the houses, inhabitants habits, and their feeling about their inside environment. The influence of these factors on IAQ is taken into account in the quality management approached developed in the "VIA-Qualité" project. The data collected in the questionnaire describing the houses are about the outside environment, the construction materials, the heating and ventilation systems, the decoration materials, furniture, etc. The habits of the inhabitants regarding heating, ventilation, cleaning, smoking, etc. that influence IAQ are collected. There is also a perceptive questionnaire about acoustic, visual, olfactory and thermal comfort of the inhabitants. A feedback on the difficulties to use the heating and ventilation systems is also asked.

Table 1. Methods and equipment used in our ventilation performance diagnostics

\begin{tabular}{|l|l|l|}
\hline \multicolumn{1}{|c|}{ Parameters } & \multicolumn{1}{|c|}{ Equipment } & \multicolumn{1}{c|}{ Reference document } \\
\hline Airflow at air terminal device & $\begin{array}{l}\text { Hood with hot wire or } \\
\text { propeller manometer }\end{array}$ & prEN16211 \\
\hline $\begin{array}{l}\text { Pressure difference at air } \\
\text { outlet }\end{array}$ & Manometer & Guide CETIAT (Caré, 2012) \\
\hline $\begin{array}{l}\text { Standardized acoustic } \\
\text { pressure level }\end{array}$ & Sound meter & ISO NF EN 10052 \\
\hline Duct air leakage & Duct leakage tester & FD E51-767, EN12237... \\
\hline
\end{tabular}




\begin{tabular}{|l|l|l|}
\hline Envelope air leakage & $\begin{array}{l}\text { Fan pressurization method } \\
\text { (Blowerdoor, Permeascope) }\end{array}$ & NF EN 13829, GA P 50-784 \\
\hline $\begin{array}{l}\text { General layouts of } \\
\text { installation }\end{array}$ & Visual inspection & $\begin{array}{l}\text { Airing regulation (JO, 1982) } \\
\text { Label Protocole (Effinergie, 2013) }\end{array}$ \\
\hline
\end{tabular}

Table 2. Measurement and analysis methods and equipment for IAQ evaluation

\begin{tabular}{|c|c|c|}
\hline Pollutants and parameters measured & $\begin{array}{c}\text { Equipment for measurement } \\
\text { and lab analysis }\end{array}$ & $\begin{array}{c}\text { Standard } \\
\text { used }\end{array}$ \\
\hline Air temperature & Thermometer & ISO 7726 \\
\hline Relative Humidity & Hygrometer & \\
\hline $\mathrm{CO}_{2}$ & $\begin{array}{l}\text { Logger using non-dispersive } \\
\text { infrared sensor }\end{array}$ & $\begin{array}{l}\text { PR NF } \\
\text { EN ISO } \\
16000-26\end{array}$ \\
\hline $\begin{array}{l}\text { VOC: benzene, toluene, ethylbenzene, }(\mathrm{m}+\mathrm{p}) \text { xylene, styrene, } \\
\text { tetrachloroethylene, } 1 \text {-methoxy-2-propanol, limonene, } \mathrm{n}- \\
\text { hexane, trichloroethylene, } 1,4-\text { dichlorobenzene, } \mathrm{n} \text {-undecane, } 2- \\
\text { butoxyethanol, alpha-pinene, o-xylène, } 1,2,4- \\
\text { trimethylbenzene. }\end{array}$ & $\begin{array}{l}\text { Radiello passive (diffusive) } \\
\text { samplers by thermal adsorption } \\
\text { Gas chromatography and mass } \\
\text { spectrometry }\end{array}$ & $\begin{array}{l}\text { ISO } \\
16017-2\end{array}$ \\
\hline $\begin{array}{l}\text { Aldehydes: formaldehyde, acetaldehyde, hexaldehyde, } \\
\text { benzaldehyde, butyraldehyde, valeraldehyde, propionaldehyde, } \\
\text { acroleine. }\end{array}$ & $\begin{array}{llrl}\text { Radiello passive } & \text { (diffusive) } \\
\text { samplers by reaction } & \text { with } 2-4 \\
\text { DNPH and } & & \text { liquid } \\
\text { chromatography } & \text { and } & \text { UV } \\
\text { detection } & & & \end{array}$ & $\begin{array}{l}\text { ISO } \\
16000-4\end{array}$ \\
\hline $\mathrm{NO}_{2}$ & $\begin{array}{l}\text { Passam AG passive diffusive } \\
\text { sampler and spectrophotometry }\end{array}$ & $\begin{array}{l}\text { NF X43- } \\
009\end{array}$ \\
\hline $\mathrm{CO}$ & $\begin{array}{l}\text { Electrochemical sensor and data } \\
\text { logger with an alert if passing } \\
\text { threshold (Drager PAC III or } \\
\text { PAC } 7000 \text { or equivalent) }\end{array}$ & $\begin{array}{l}\text { NF EN } \\
14626\end{array}$ \\
\hline PM 2,5 & $\begin{array}{l}\text { Active air sampling on a filter } \\
\text { with a pump }\end{array}$ & $\begin{array}{l}\text { NF EN } \\
14907\end{array}$ \\
\hline Radon & $\begin{array}{l}\text { Passive sampling with Alpha } \\
\text { track detection }\end{array}$ & $\begin{array}{l}\text { ISO } \\
11665-4\end{array}$ \\
\hline
\end{tabular}

\section{RESULTS AND DISCUSSION}

With the first campaign, we are able to identify ventilation dysfunctions and to compare them with the national statistics. No house is found to comply fully with the ventilation regulation, 2 of them with minor non-compliances. The main non-compliance points are given in Figure 1a classified by type of the installation concerned. We can note than there are generally several non-compliance on the same installation (average 3 per inspected house). As a result, we can note that $81 \%$ of the houses don't reach the minimum required total airflows (standard running mode), including $82 \%$ under-ventilation rates and $18 \%$ over- ventilation rates. Figure $1 \mathrm{~b}$ shows the relative gap of the measured total airflows to the minimum required airflows, by compliance category. For over-ventilated houses ( 3 cases), the relative gap median value is $+39 \%$; for regulatory ventilated houses ( 4 cases) it is $+22 \%$, for underventilated houses (14 cases) it is $-45 \%$, with a maximum value of $-73 \%$.

$100 \%$ of tested houses ( 7 cases) do not comply with the boost mode required in kitchen (when cooking), even those over-ventilating have difficulties achieving the maximum flow. Figure 2 shows that around 50\% of the ducts, including exhaust- and supply duct, have an airleakage class greater than or equal to 3 times the class A, which is the worst class according to EN 14239 (CEN, 2004). 

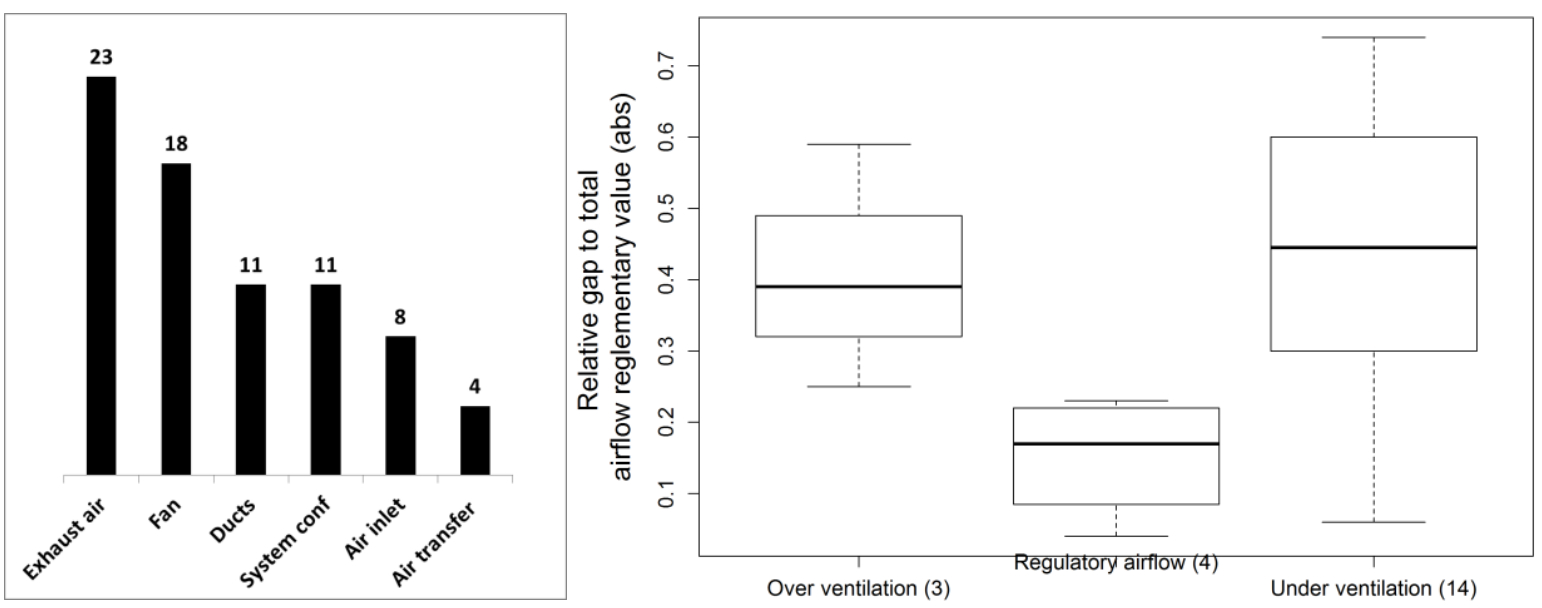

Figure 1. Non-compliances on inspected ventilation systems. a) Number by type, b) Measured total airflows: relative gap to regulatory values according to the compliance category.
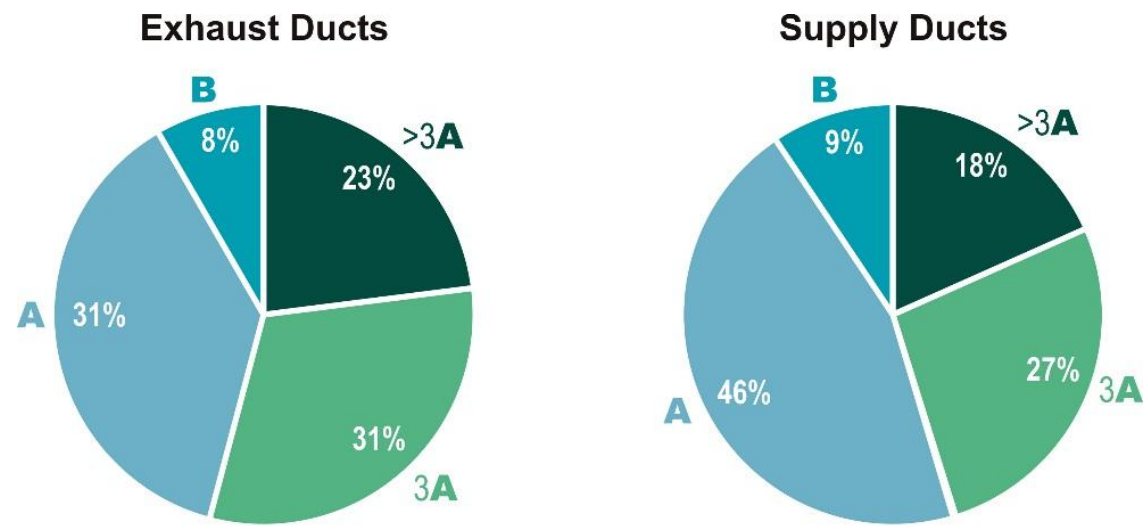

Figure 2. Duct air-tightness on: a) exhaust, b) supply ducts

It is therefore essential to check why these airflows are not obtained. We have classified, for each installation, the main non-compliance leading on these installations to a poor compliance of airflows (Figure 3). Firstly, the lack of flow control devices is recurrent and doesn't allow achieving a correct airflow in kitchen even when the fan is boosted, flow controls are mandatory in the French thermal regulation as well as in airing one. Secondly, ducts are the main cause of problem mainly through: poor air tightness loosing flow, too high pressure drop, causing lack of airflows at some air terminals, air exhaust ducts too small, sometimes not even connected or connected to roof outlet too small creating too much pressure drop. Thirdly, poor fan connections create too much pressure drop and a lack of access. And finally, in one case, the large outdoor pollution fills in the filters (no prefilter, F7 alone) and reduces the airflow to zero after 2 months, in widely polluted area, a specific care to filtration is needed. 


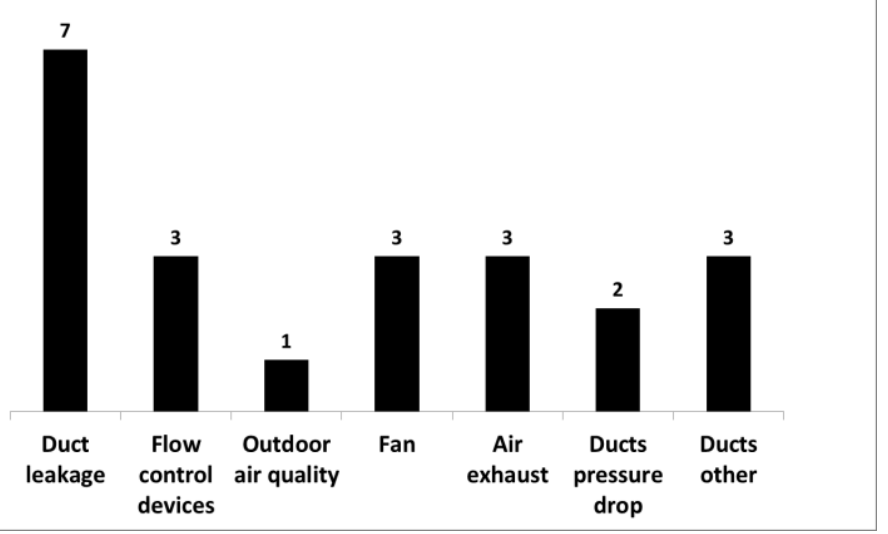

Figure 3. Main causes of non-compliance on airflows

These defaults are very recurrent and can be solved easily. Pressure drop is not calculated in most cases in individual houses because it used to be generally simple in single exhaust systems and to save time. The QM approach will have to recommend a pressure drop calculations on systems installed, mainly for supply and exhaust systems, but also for single exhaust if used components sizing are not strictly checked. Most other defaults are linked with incorrect practice in mounting and assembling the ventilation system. Training is a large part of the QM approach and will be addressed through specific guidelines in the next steps of "VIA-Qualité" project. Solving this kind of defaults should not increase the cost of the installation and need to be done because we can guess there will be a large impact on IAQ results and thermal performance (ie : $14 \%$ of dwellings over-ventilating, sometimes up to 3 times the mandatory airflow is a waste of energy to be considered).

The second measurement campaign allows us also to analyze links between ventilation diagnosis and indoor pollutant measurements. Firstly, we observe that the formaldehyde median value of the 20 measurement points is $17.4 \mu \mathrm{g} / \mathrm{m}^{3}$, lightly under $19.6 \mu \mathrm{g} / \mathrm{m}^{3}$, the median value measured during the national campaign on dwellings (OQAI, 2003-2005). In addition, only bedrooms were measured during this national campaign. If we would compare more precisely, we should also use the median value of the 10 measurement points in the bedrooms, which is even lower: $17.25 \mu \mathrm{g} / \mathrm{m}^{3}$.

An interesting result concerns links between ventilation level and VOCs and aldehyde concentrations (Figure 4): The three over ventilated houses have lower concentrations while in the 2 regulatory houses and in the 5 under ventilated houses results are diverse. This observation is balanced by the fact that IAQ is connected to ventilation quality, but also to building materials, decorations, and furnishings, to occupant behaviors, to outdoor environment.
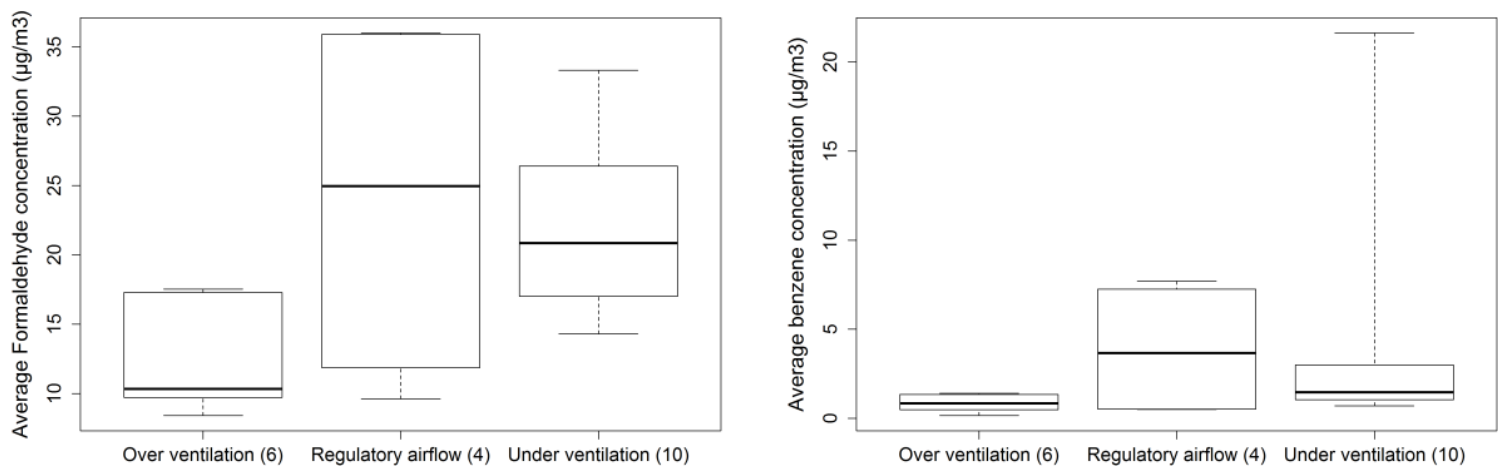

Figure 4. Average concentration distributions, according to the compliance category for: a) Formaldehyde, b) benzene. 
Then, it is clear with $\mathrm{CO}_{2}$ concentrations analysis (Figure 5) that problems in bedrooms occurs when the ventilation operates improperly (insufficient rates, or doors not correctly undercut). Case $n^{\circ} 2$ shows that even the global airflow is correct, bad doors undercuts can explain high $\mathrm{CO}_{2}$ concentrations especially in main bedroom. We consider the limit of 1000 ppm (JO, 1978), the number of hours in a week with concentration higher than $1000 \mathrm{ppm}$, and the average of the 60 highest values (OQAI, 2006) as a performance indicator.

Then, we observe that the presence of an attached garage with access to the house can explain a part of high BTEX concentrations, but it is not a general explanation (Figure 6).

In no house, relative humidity median value is higher than $60 \%$, and no fungal contamination is observed.

Finally, a very critical case is underlined with high $\mathrm{CO}$ concentration in the presence of ventilation- and wood stove-dysfunctions.

We observe no specific difference between balanced and single exhaust systems, even if our sample is very little.

\begin{tabular}{|c|c|c|c|c|c|c|c|}
\hline \multirow[b]{2}{*}{$\begin{array}{l}\text { House } \\
n^{\circ}\end{array}$} & \multicolumn{2}{|c|}{$\begin{array}{c}\qquad \mathrm{CO}_{2}(\mathrm{ppm}) \\
\text { Average value of the } 60 \text { highest values }\end{array}$} & \multirow{2}{*}{$\begin{array}{c}\text { Number of } \\
\text { hours per week } \\
>1000 \mathrm{ppm} \text { in } \\
\text { bedroom }\end{array}$} & \multicolumn{4}{|c|}{ Ventilation Performance } \\
\hline & Living room & Bedroom & & $\begin{array}{c}\text { Base airflow } \\
\% \text { of regulatory airflow }\end{array}$ & $\begin{array}{c}\text { Doors with } \\
\text { no undercut }\end{array}$ & $\begin{array}{c}\text { Duct air } \\
\text { leakage } \\
\text { (NF EN 12237) }\end{array}$ & \begin{tabular}{|c|} 
Balancing \\
between exhaust \\
and supply
\end{tabular} \\
\hline 1 & 1442 & 2210 & $12,5 \mathrm{~h}$ & $-35 \%$ & Compliant & $3 \mathrm{~A}$ & $0,40 \%$ \\
\hline 2 & 1130 & 2177 & $85 \mathrm{~h}$ & Compliant & No compliant & not measured & N/A \\
\hline 3 & 717 & 1062 & $15,5 \mathrm{~h}$ & $-50 \%$ & Compliant & $3 A$ & $13 \%$ \\
\hline 4 & 1111 & 2351 & $47 \mathrm{~h}$ & $-40 \%$ & Compliant & not measured & N/A \\
\hline 5 & 642 & & & $+37 \%$ & No compliant & $3 \mathrm{~A}$ & $23,10 \%$ \\
\hline 6 & 734 & 728 & $\mathrm{Oh}$ & $+39 \%$ & Compliant & $3 A$ & not measured \\
\hline 7 & 875 & 1503 & $22 \mathrm{~h}$ & $-74 \%$ & Compliant & $3 A$ & $48 \%$ \\
\hline 8 & 979 & 1666 & $57 \mathrm{~h}$ & $-13 \%$ & Compliant & A & $26 \%$ \\
\hline 9 & 661 & 993 & $1 \mathrm{~h}$ & $+59 \%$ & Compliant & A & $5 \%$ \\
\hline 10 & 563 & 1044 & $5 \mathrm{~h}$ & Compliant & Compliant & $3 \mathrm{~A}$ & $0,30 \%$ \\
\hline
\end{tabular}

Figure 5. Analysis of carbon dioxide concentrations regarding ventilation dysfunctions

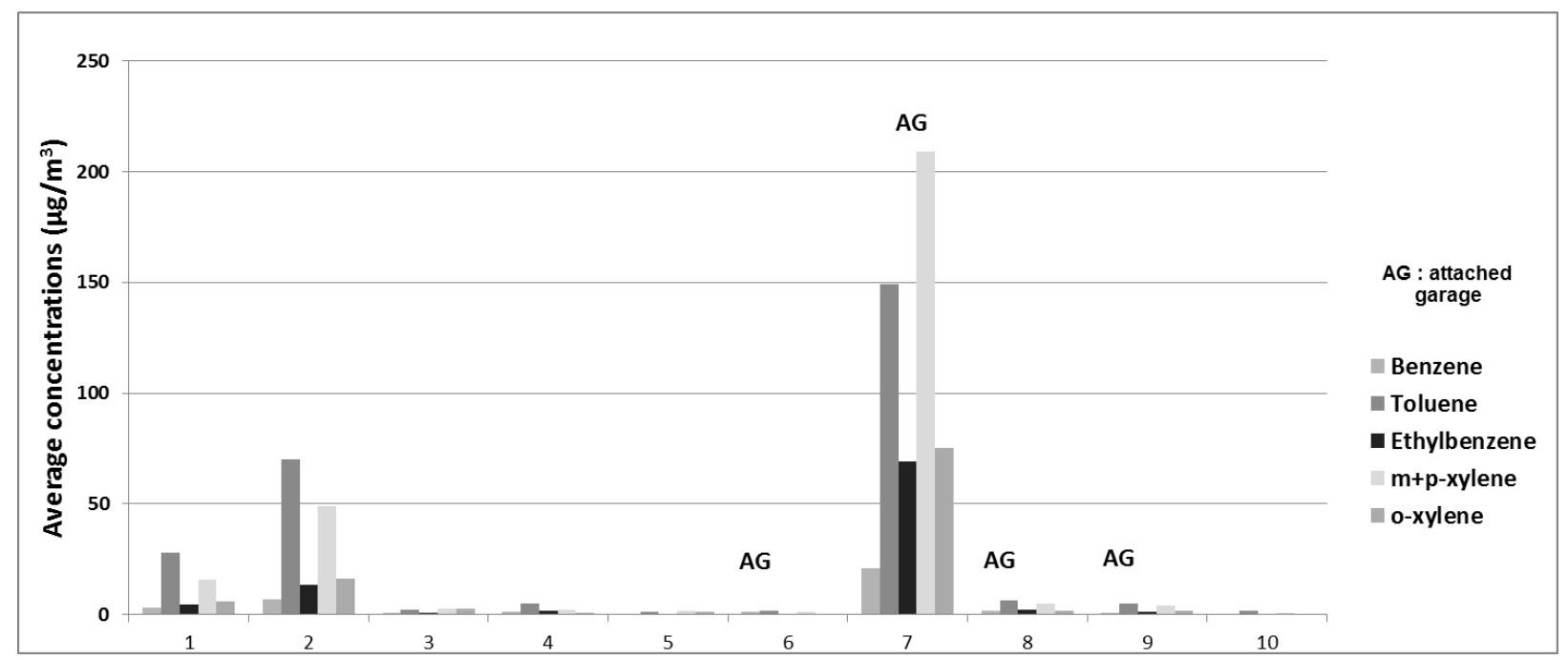

Figure 6. BTEX concentrations in living rooms of the 10 houses, regarding the presence of an attached garage

\section{CONCLUSIONS}


With this campaign on 21 low-energy single-family dwellings, we would like to produce precise crossed data on: 1-quality of in-site ventilation and 2-pollutants in indoor air of low energy single-family dwellings, representative for French new low-energy houses.

With the first campaign, we were able to identify ventilation dysfunctions and to compare them with the national statistics. No house was found to comply fully with the ventilation regulation, 2 of them with minor non-compliances. Concerning the ventilation rates, $81 \%$ of the dwellings do not respect requirements, including $82 \%$ over-ventilation rates and $18 \%$ under ventilation rates.

The second measurement campaign allowed us also to analyze links between ventilation diagnosis and indoor pollutant measurements. First results are: Pollutant concentrations are slightly under the median values measured during the national campaign on dwellings (OQAI, 2003-2005) for formaldehyde even if they stay under the French guide value of $30 \mu \mathrm{g} / \mathrm{m}^{3}$; Over ventilated house have lower VOCs and aldehydes concentrations; In regulatory and under ventilated houses results are diverse; No specific difference is noted between balanced and single exhaust systems. A critical case was underlined with high $\mathrm{CO}$ concentration in the presence of ventilation- and wood stove-dysfunctions.

This analysis confirms that, even if adapted industrial solutions are available, ventilation system dysfunctions are very frequently observed in low-energy dwellings like in every dwelling (Jobert and Guyot 2013), which entails the reliability of these installations.

The main stake now consists in developing tools leading to better practices at every stage of the construction. In this project, we want to show that many dysfunctions could be avoided through the implementation of quality management tools. With such tools, one could pretty easily, not costly, but efficiently, control ventilation system at each stage of the building construction: from design to installation, even including maintenance and final use. We could also manage and limit indoor air pollutants.

In the VIA-Qualité project, we are now testing these tools with the construction of 8 pilot projects of low energy houses, thanks to two builder's partners. We are going to measure ventilation and IAQ performances at commissioning and during the 6 first months for IAQ on 2 houses.

\section{ACKNOWLEDGEMENT}

The "VIA-Qualite" project has received funding from the French Environment and Energy Management Agency under the contract ADEME/1304CO014 and from the Rhône-Alpes Auvergne region. The contribution of CEREMA is funded by the French ministry for environment, see, and energy (MEME).

The sole responsibility for the content of this publication lies with the authors.

\section{REFERENCES}

Boersta A (2012) Residential ventilation system performance: outcomes of a field study in the Netherlands. Conference paper, AIVC, Tightvent, Copenhague, Denmark, 7 p.

Boulanger X et al (2012) Lessons learned on ventilation systems from the IAQ calculations on tight energy performant buildings. 33th AIVC Conference, Copenhagen, Denmark, $7 \mathrm{p}$.

Caré I, Chaffois P, Henry P (2012) Guide de bonnes pratiques des mesures de débit d'air sur site pour les installateurs de ventilation. CETIAT, www.cetiat.fr, France, 49 p.

CEN (2004) EN 14239:2004. Ventilation for buildings. Ductwork. Measurement of ductwork surface area

Charrier, S., Ponthieux, J., Huet, A. (2014). The Airtightness Quality Management Approach in France - Assessment after more than Five Years of Operation. International Journal of Ventilation. ISSN 1473-3315. Vol. 13(2), pp. 125-140.

Caillou S (2012) Performances of ventilation systems: on site measurements related to energy efficiency, comfort and health. 33th AIVC Conference, Copenhagen, Denmark, 7 p. 
Carrié R et al. (2007) Performance de la ventilation et du bâti. Rapport final phase 1 et 2, Association air.h, France, 109 p.

Effinergie (2013) Protocole de contrôle des systèmes de ventilation des bâtiments demandant le label Effinergie +, France, www.effinergie.org, 12p.

Erhorn H, Erhorn-Kluttig H, Carrié F.R (2008) Airtightness requirements for high-performance buildings. Conference paper, AIVC, Kyoto, Japan, 6 p.

JO (1978), Circulaire du 9 août 1978 relative à la révision du règlement sanitaire départemental (RSDT)

JO (1982), Arrêté du 24 mars 1982 consolidée relatif à l'aération des logements : aération générale ou permanente. JO du 15 novembre 1983.

Jobert R, Guyot G (2013) Detailed analysis of regulatory compliance controls of 1287 dwellings ventilation systems, 34th AIVC Conference, Athens, Greece, 2013, 10 p.

OQAI (2006), Campagne nationale logements : état de la qualité de l'air dans les logements français rapport final. Novembre 2006, mis à jour mai 2007. DDD/SB 2006-57. 183p.

OQAI (2013), Base de référence sur la qualité de l'air intérieur, le confort et les consommations énergétiques des bâtiments performants en énergie - stratégie générale de collecte des données, Protocole n ${ }^{\circ}$ OQAI - CSTB - 2012 - 106, février 2013, 31p.

Wargocki P, Hartmann T (2012) Health-Based ventilation Guidelines for Europe. HealthVent project, 33th AIVC Conference, Copenhagen, Denmark. 